\title{
THE AZOV-BLACK SEA REGION AS A CROSSING OF CULTURES: FACTORS, STAGES, OUTCOMES OF PROCESSES OF CULTURAL INTERINFLUENCE
}

\author{
(C) Natalia V. Shishova, Vitaliy A. Bondarev, Ruslan G. Tikidzhian \\ Don State Technical University, Rostov-on-Don, Russian Federation \\ nshishova@donstu.ru \\ vitalijj-bondarev27@rambler.ru \\ ruslan.kazak61@gmail.com
}

The issue of cultural interaction is highlighted, the relevance of which has increased significantly in the context of the world's growing confrontation between globalization and counter-globalization. The urgency of this problem is evident in Russia as in the multinational State. One of the regions where such interaction took place most actively is the Azov-Black Sea region. The article examines the dynamics of cultural interinfluence processes in the region. The retrospective analysis has been carried out, which makes it possible to conclude that historically the Azov-Black Sea region has been a crossing of civilizations, where the migratory flows of Western and Eastern civilizations have been directed and where representatives of these civilizations have come into contact with each other. Periodization of intercultural contacts in the region, including a number of qualitatively different stages is supposed. It has been proved that within the boundaries of various stages the cultural influence of various peoples and civilizations has prevailed: the Greeks and the Romans, the Turkicspeaking nomads, the Turks, the Cossack communities, the Russian Empire. While in the era of antiquity the leading role in intercultural interaction was played by the Greeks and then by the Romans, who had a stimulating and guiding effect on the Iranian-speaking nomads of the Scythians and the Sarmatians, in the Middle Ages the situation changed seriously, which was connected with the collapse of the Graeco-Roman colonies due to the arrival of a new wave of nomads, this time Turkic-speaking, in the region. It is noted that the brightest example of active inter-ethnic and intercultural contacts in the Azov-Black Sea region and, at the same time, the extreme importance of these contacts in giving vitality to certain communities and state entities, is the Cossacks, which arose as a result of interaction of a number of different ethnocultural communities. The valid conclusions are the following, first, the leading trends in the Azov-Black Sea region were active inter-ethnic (intercultural) contacts, which resulted not only in the mutual enrichment of cultures and lifestyles of their participants, but also in the formation of new communities, such as the Cossacks; second, these contacts have acted and continue to act as a means of cementing and stimulating the development of multi-ethnic State entities, including Russia.

Key words: the Azov-Black Sea region, the Cossacks, intercultural communications, the Northern Black Sea region, ethnocultural dynamics.

[Н.В. Шишова, В.А. Бондарев, Р.Г. Тикиджьян Азово-Черноморье как перекресток культур: факторы, этапы, результаты процессов культурного взаимовлияния]

Освещается проблема культурного взаимовлияния, актуальность которой заметно возросла в условиях наблюдающегося в мире обострения противоборства между процессами глобализации и контрглобализации. Острота данной проблемы весьма ощутима в России как многонациональном государстве. Одним из регионов, где подобное взаимодействие проходило наиболее активно, выступает Азово-Черноморье. В статье рассматривается динамика процессов культурного взаимовлияния в данном регионе. Проведен ретроспективный анализ, который позволяет заключить, что Азово-Черноморье исторически выступало перекрестком цивилизаций, куда направлялись миграционные потоки Западной и Восточной цивилизаций и где представители данных цивилизаций вступали в контакты друг с другом. Предложена периодизация межкультурных контактов в регионе, включающая в себя ряд качественно различных этапов. Доказано, что в границах различных этапов превалировало культурное влияние различных народов и цивилизаций: греков и римлян, тюркоязычных кочевников, турок, казачьих сообществ, Российской империи. Если в эпоху античности ведущую роль в межкультурном взаимодействии играли греки, а затем римляне, оказывавшие стимулирующее и направляющее воздействие на ираноязычных кочевников скифов и сарматов, то в Средние века ситуация серьезно изменилась, что было связано с крахом греко-римских колоний вследствие прихода в регион новой волны номадов, на сей раз тюркоязычных. Отмечается, что ярчайшим примером активных межэтнических и межкультурных контактов в Азово-Черноморье и, одновременно, чрезвычайной 
важности этих контактов в плане придания жизнеспособности тем или иным сообществам и государственным образованиям, выступает казачество, возникшее как результат взаимодействия целого ряда различных этнокультурных общностей. Обоснованы выводы, что, во-первых, ведущей тенденцией применительно к Азово-Черноморскому региону являлись активные межэтнические (межкультурные) контакты, результатом которых являлось не только взаимообогащение культур и образа жизни их участников, но и формирование новых общностей, таких, как казачество. Во-вторых, эти контакты выступали и продолжают выступать в качестве средства, цементирующего основы и стимулирующих развитие полиэтнических государственных образований, к числу которых относится и Россия.

Ключевые слова: Азово-Черноморье, казачество, межкультурные коммуникации, Северное Причерноморье, этнокультурная динамика.

Natalia V. Shishova - Ph.D. in History, Associate Professor, Don State Technical University, Rostov-on-Don, Russian Federation.

Vitaliy A. Bondarev - Ph.D. (Advanced Doctorate) in History, Professor, Don State Technical University, Rostovon-Don, Russian Federation.

Ruslan G. Tikidzhian - Ph.D. in History, Associate Professor, Don State Technical University, Rostov-on-Don, Russian Federation.

Шишова Наталья Васильевна - кандидат исторических наук, доцент, Донской государственный технический университет, г. Ростов-на-Дону, Российская Федерация.

Бондарев Виталий Александрович - доктор исторических наук, профессор, Донской государственный технический университет, г. Ростов-на-Дону, Российская Федерация.

Тикиджьян Руслан Геннадьевич - кандидат исторических наук, доцент, Донской государственный технический университет, г. Ростов-на-Дону, Российская Федерация.

One of the most characteristic phenomena of the modern era is the growing confrontation between globalization, recently victorious around the world, and growing counter-globalist processes, the growth of national identity, struggle for preservation of national identity, cultural traditions, etc. The question of principles and norms of coexistence of different peoples and cultures becomes vital for Russia as a multi-ethnic State. The policy of multiculturalism, which for some time seemed to be the most correct and generally accepted answer to this question, has now been criticized. Admittedly, this criticism is well founded, because, as the experience of a number of European countries shows, this policy has considerable conflictogenic potential because of the actual encouragement of the cultural autarky of certain ethnic groups, which thus oppose the ethnic group dominant in a particular State. The target for critical arrows is also the well-known "melting pot" theory for offering mixing (fusion) of different cultures, which thus lose their unique appearance, their self and dissolve in the qualitatively new, unique ethnocultural community, originating from this mixing.

In theory, a kind of "the golden mean" seems to be active intercultural communication, interpenetration and mutual enrichment of cultures coexisting in a certain territory, in which the danger of autarky as a source of intercultural conflicts is eliminated and, at the same time, the fundamental right of peoples to preserve their traditions, customs and way of life is not violated. Although in the practical plane such theoretical constructions can hardly be implemented in pure form, history presents us with many examples of coexistence and mutual enrichment of various ethno-cultural communities, which took place even in the conditions of a frontier. Moreover, there are a number of regions in the world where, due to the specific conditions, cultural exchange took place and takes place most actively. Such regions include the Azov-Black Sea region. For this reason, in this publication we have attempted to highlight the factors, stages and outcomes of cultural exchange processes that have unfolded in our region over centuries and millennia. It is supposed that the results of scientific analysis of these processes with good reason can be considered as one of the 
conditions for successful prevention of such acute and dangerous problems of modern times as inter-ethnic discord, chauvinism, fascism.

The fact that the Azov-Black Sea region has become a crossing of cultures and civilizations since deep antiquity is primarily due to the natural and geographical conditions of the region. The Northern Black Sea region and Pryazovia were a part of the steppe corridor, along which numerous hordes of nomads, whether the Iranian-speaking Scythians and Sarmatians, the Turkic-speaking Pechenegs and Polovtsians, the Mongol-Tatars, and others, came here repeatedly from the Asian steppes. At the same time, the presence of Bosphorus and Dardanelles straits between the Black Sea and the Mediterranean Sea led to the active development of the rich Black Sea coast by the developed States of the Mediterranean. Such was Greek colonization when ships with Greek emigrants reached the Northern Black Sea and founded colonies here. Thus, it is possible to distinguish two main directions of migration to the Azov-Black Sea region: Eastern (nomads from Asia) and Western or South-Western (seafarers, inhabitants of Mediterranean States, the Greeks, the Romans, the Byzantine Empire). The exception to this rule was the "unprecedented movement" [14, p. 81] of the German tribes of the Goths which moved here from the north-west, from the coast of Vistula, i.e. from the territory of modern Poland (where, in turn, came from Scandinavia) to the Northern Black Sea in the 3rd century AD. The pronounced polarity of migrations in the AzovBlack Sea region, when representatives of completely different civilizations met in the region, generated unique results of intercultural communications.

The review of migrations to the Azov-Black Sea region makes it possible to develop their periodization, which is based on the account of ethnocultural communities that dominated in the region during a certain period of time. Of course, this periodization, like any other, can be further developed and supplemented. Nevertheless, in our opinion, it adequately reflects the ethnocultural dynamics within the borders of the Azov-Black Sea region. In our view, the suggested periodization should include the following main stages:

1) From ancient times to the 8th century $B C$ - the stage of existence in the region of pit, catacomb, blockhouse cultures;

2) From the 8th century BC to the 4th century $A D$ - "Greek" and "Scythian and Sarmatian" stage of the region's history, during which the paramount importance in its ethnocultural, socio-economic, political development belonged to Greek colonies, Scythian and Sarmatian tribes. In addition, in the beginning of $A D$, the Roman Empire also played an important role in the region, and since the 3rd century $A D$, as already indicated, the Goths who came from the north-west;

3) From the 4th to the 16th centuries - the period of the Middle Ages, the beginning of which in our region, seems to us, was the invasion of the Huns, who dealt a fatal blow to the Graeco-Roman cities as a center of ancient culture. It is necessary to mention the Byzantine Empire, the Khazars, the Pechenegs, the Polovtsians, the Mongol-Tatars and, finally, the Turks among ethnic groups and States which dominated in this period. Some role in the development of the region was played by the Italians, who created a number of trading colonies here (so to speak, the "second coming of Italy" in the Azov-Black Sea region, if the first is to be understood as Roman expansion);

4) From the 16th to the 17th centuries - the stage of formation and activity in the region of independent self-governing Cossack communities, which represented an excellent model of ethnic and cultural openness;

5) The 18th century (our time) - this stage is characterized by the entry of the AzovBlack Sea region into the Russian State, in connection with which, ethnocultural processes have largely become manageable, and intercultural interpenetration has intensified and accelerated due to both indirect and targeted influence of the state apparatus. 
Of course, within the narrow framework of the publication, it is not possible to detail the trends and peculiarities of the processes of cultural interaction and interinfluence within all the stages we have identified. In this regard, let us limit ourselves to a brief overview of only a few of them, which most clearly show that the Azov-Black Sea region was a region of active ethno-cultural contacts. We consider that in the forefront there is a stage of Greek colonization of the northern coast of the Black Sea and domination of the Scythians and then the Sarmatians in the Black Sea steppes.

Since the 8th century, in the Northern Black Sea region the Scythians asserted their power, which are rightly characterized by researchers as "a new stage and a higher stage in the history of human development" [7, p. 33] in the region. The Scythians conquered the local tribes and "literally like a flurry hurricane flew" through the neighboring territories "up to Syria and Egypt" [14, p. 195]. In addition to military campaigns and invasions, the Scythians maintained peaceful contacts with neighboring States and tribes. In particular, archaeological excavations of burials of the 8th-7th centuries BC show "close ties of the population of the North-West Caucasus with the world of Iranian nomads of South Russian steppes, the Cimmerians, the Scythians, the Sarmatians" [3, p. 31].

Somewhat later, from the 6th century BC. the city-states of mainland Greece and Asia Minor, attracted by the natural wealth of the Northern Black Sea region and the prospects of profitable trade to the local population, started a large-scale colonization of the region. The Greek city of Millet in Asia Minor played a leading role in colonization. During colonization in the Northern Black Sea region "flowering Greek colonies" appeared [1, p. 5], among them there was Olbia on the right bank of the Dnieper-Bug estuary, Tanais at the mouth of Don, colonies in Crimea and on the Taman Peninsula (Chersonese, Panticapaeum, Feodosiya, Phanagoria, etc.). The Greeks numbered up to 200 settlements founded by them on the North Coast of the Black Sea [7, p. 50].

Figuratively speaking, in cultural and domestic terms the colonies were exact copies of the mother country transferred to the territory of barbarians. Thus, Olbia's excavations demonstrate that it was built as a usual Greek city-state. The city was surrounded by monumental walls and towers folded from "perfectly made stone bricks (quadra)". There was agora, temples of Greek gods, houses with a central courtyard and rooms located around it characteristic for the Hellenic world [8, pp. 90-91].

The Greek colonies traded with the barbaric tribes that surrounded them and, most notably, with the Scythians as the region's dominant tribal association. At the same time, there was an active cultural exchange between the Greeks and the Scythians. The Greeks perceived certain components of the Scythian culture. In particular, they borrowed words from the Scythian language, as a result of which a mixed Graeco-Scythian dialect arose in the colonies of the Northern Black Sea region. However, the cultural impact of the colonists on the barbaric world surrounding them was incomparably stronger, which, of course, was not an accident. Speaking about interaction of two societies, as a rule, the society with a higher level of development will have a more significant or even decisive impact on the other. This was also the case with the Scythians, who fell under the serious influence of the Greeks.

Greek influence is clearly expressed in the material culture of the Scythians. Digging up graves of Scythian nobility (famous Scythian mounds) in the Azov-Black Sea region, archeologists find expensive weapons and armor, precious vessels, made by the Greeks, as well as jewelry, "a significant part of which come from jewelry workshops of Greek cities" [1, p. 3]. It is significant that these things often depict scenes from Greek myths. Thus, during excavations of Scythian burials the gorytus (case for bow and arrows) with a gold lining decorated with scenes from the life of the mythical hero Achilles was found near Elizavetinskaia village on the Don [6, p. 10]. It is necessary to think that the natural consequence of placing scenes from Greek myths on things intended for the Scythians was 
not only familiarity of the latter with mythology, religion and, in general, with the culture of the Greeks, but also formation of positive attitude to this culture and, as a result, readiness to perceive it.

It is obvious that Greek influence on the Scythians was not limited only to the sphere of material culture, but went on, affecting and changing the way of life of nomads to some extent. Herodotus claimed that "the Scythians, as well as other people, also persistently avoid foreign customs..., especially Hellenic", citing as an example the sad fate of the Scythians Anacharsis and Scyles killed by tribespeople for commission of the Greek ceremonies and wearing the Greek clothes [4, pp. 41-44]. It is quite possible that in the early stages of Graeco-Scythian contacts it happened. But the longer the Scythians were in contact with the Greek colonies of the Azov-Black Sea region, the more significant changes took place in their lives under the influence of a more developed civilization. Ultimately, the existence in the Azov-Black Sea region of "ancient cities and later, states such as the Bosporan Kingdom, contributed to the acceleration of the process of disintegration of maternity relations among local farmers and nomads..." [9, p. 44]. The late Scythians of the 4th-2nd centuries BC had been already significantly different from the Scythians of the 5th century BC described by Herodotus, as they built cities, minted their own coins, etc. In other words, "the late Scythians, especially those drawn into the sphere of economic and political influence of the colonies of the Graeco-Roman slave-owning world, had already entered the stage of social development that was consistent with the division of society into classes and the emergence of the State" [7, p. 47]. Of course, one of the factors of demoralization of tribal relations and formation of the Class State among the Scythians should be considered the modernizing effect of Greek colonies on nomads.

In the 1st century BC, a new major player, Rome, appears in the Northern Black Sea region. In $45 \mathrm{AD}$ units of the Roman army first appeared in Crimea, in 65 the Kingdom of Pontus became the Roman province, a State formation on the southern shore of the Black Sea. The Bosporan Kingdom on the shores of the Cimmerian Bosporus (the present-day Strait of Kerch) with the capital Panticapaeum became dependent on the Romans [10, 8, $p$. 11]. Under the Romans, the Black Sea region was in the range of ancient culture as previously under the Greeks.

Nevertheless, the era of antiquity was steadily leaning towards its sunset, and in the 4th century AD the Azov-Black Sea region was subjected to the invasion of the Huns, that arose as a result of mixing of tribal confederation of nomadic peoples, the Xiongnu, living in the steppes north of China with "pro-Turkish, Ugric and Sarmatian tribes" [3, p. 46].

After the collapse of the fragile Hun power in the 5th century, the steppes of the AzovBlack Sea region became an arena of migration and confrontation between various nomadic tribes. In the 7th century, the Khazar Kaganat, a State formation created by the Turkicspeaking Khazar nomads that dominated not only the tribes of the Caucasus (particularly the Alans), but also a number of East Slavic tribal associations, emerged in the region. Hazar power extended to Crimea, and here they were adjacent to the possessions of such a rich and powerful State as the Byzantine Empire. After all, Chersonesus was founded as a Greek colony in the 5th century BC and became a part of the Byzantine Empire a thousand years after its emergence, belonged to its rulers.

Within the borders of the Khazar Kaganat, taking into account the diverse ethnic composition of the State, cultural exchange between the tribes that inhabited it seemed inevitable. In addition, Khazaria was influenced by the Byzantine Empire, which considered the Kaganat to be its ally in the Black Sea region. As is known, at the request of the Khazars, the Byzantine Emperor Theophilos told his masters to build the fortress Sarkel on the bank of the Don, which was built in the 30s of the 10th century. Judging by the materials of archaeological excavations carried out, before the waters of Tsimlyansk Reservoir closed 
over the ruins of Sarkel, the walls of the fortress were built from the typical for the Byzantine architecture burnt plinthiform brick. The fortress was a quadrangle, in one of its corners the square tower-donjon rose [11, p. 23].

When in 965 the Kiev Prince Sviatoslav Igorevich destroyed the Khazar Kaganat, Sarkel turned into White Veja, the Slavic settlement ("White Tower", translation into Russian from the Turkic name of the fortress). At the same time, some part of the local population was a Turkic element, among which there were probably the surviving Khazars. At least, it is believed that after the campaigns of Svatoslav "the remains of the autochthonous Khazar population became a part of the ancient Russian ethnic group on the rights of the subgroup, which was called the Brodnici" [9, p. 66]. In this case, here is another example of deep cultural and ethnic contacts in the Azov-Black Sea region, this time with the participation of Eastern Slavs.

In the 10th-13th centuries in the steppes of the Azov-Black Sea region the Pechenegs were interspersed with the Polovtsians, the Mongol-Tatars successively. Created by the Mongolian Khans, the Golden Horde became another multi-ethnic State in our region, within the borders of which there was a cultural exchange between various tribes and peoples. The impact of the Tatars on the Russian lands subordinate to the Golden Horde is undeniable, as evidenced by the numerous Turkisms in the Russian language, the orientalization of offensive and protective weapons of Russian warriors, the traditions of eastern despotism accepted by the Muscovite state, etc.

The event that deserves to be mentioned separately is the emergence of Italian colonies in the Black Sea region, within the boundaries of the Golden Horde. The expansion of the Italians (especially Venice and Genoa) to our region had taken place since the middle of the 13th century and was caused by several factors, among which one of the most significant was the weakening of the Byzantine Empire. At the end of the 13th and beginning of the 14th centuries, at least 39 Italian colonies were established on the east coast of the Azov sea and the Black sea, ruled by consuls or baili, with their own administrative structures and garrisons. The most significant of these were Matrega (Taman Peninsula), Mapa (Anapa), Copa (Slavyansk-on-Kuban), etc., founded by the Genoese. The Venetians founded the colony of Tana, the northernmost Italian colony in the region, located on the left bank of the Don on the site of modern Azov [14, p. 109].

The Italian colonies, the largest of which minted their own coin, had a serious impact on the economic development of our region. However, their condition was negatively affected by the general instability in the disintegrating Golden Horde, which was engulfed in strife. Tamerlane struck the Italian colonies during his campaign against the Golden Horde in 1395. The colonies ceased to exist because of the conquest of the Azov-Black Sea region by the Turks in the 1470s [14, p. 109]. At the same time, Turkish fortresses had already emerged on the site of certain colonies, indicating their strategic advantage. In particular, Italian Tana had become Turkish Azak, which today is known as Azov.

In the 16th century Cossack communities appeared on the Don, which became a sign of the return to the Azov-Black Sea region of the Slavonic element (for the first time after the 10th-11th centuries, when the Russian settlements were White Veja on the Don and Tmutarakan on the Taman peninsula). According to the researchers, the Cossacks "recognized themselves as a part of the Russian people, and the places of their settlements were considered a part of Russia" [12, p. 8]. However, the Cossack communities were open to anyone wishing to join, regardless of ethnicity. For a long time... "the Cossacks were quite indifferent to the nationality and class origin of those whom they accepted into their ranks," so that "the Nogai Tatar next to the former Ryazan man, the impoverished son of boyar under the leadership of the kholop" was "a common combination even for the 17 century." [12, p. 8]. On this occasion, the former copyist of Ambassadorial Prikaz, Grigory Kotoshikhin, wrote with 
knowledge of the case about the Cossacks: "They are people from Moscow and from other cities, and the newly crossed Tatars, and the Zaporozhye Cossacks, and the Polacks, and the Poles..." [5, p. 159].

Due to their openness, the Cossacks had become a unique mixture of various ethnic groups and cultures. The appearance of the Cossacks, their sub-dialect, suit, weapons complex, all this clearly demonstrated that the Cossacks were formed on the basis of the Russian element, but under the strongest influence of the Tatars, the Turks, peoples of the North Caucasus, etc. In other words, the Cossacks acted as one of the most striking examples of the successful ethnocultural interpenetration so characteristic for the Azov-Black Sea region.

From the end of the 17th century, the Russian state began to explore Pryazovia and the Black Sea region, achieving impressive results by the end of the 18th century, when Turkish influence in the region was reduced to zero, the Crimean Khanate ceased to exist, and in the previously desert territories Novorossiya appeared and began to be actively settled.

In the development of the Northern Black Sea region during the imperial period, foreigners, both in Russian service and who arrived in the newly annexed territories of Russia as settlers, played a very important role. Thus, one of the builders of Taganrog, founded in 1698, was the Italian engineer-captain Matthew Simont, whose work was greatly appreciated by Peter I. When, after the brilliant victory in the second Russo-Turkish War of 1787-1791, the Russian Empire established full control over the Northern Black Sea region and was concerned about the consolidation of the annexed territories, José de Ribas became the founder and builder of such an important port city as Odessa. He was a Spanish military officer from Naples, in Russian service, who "tried to adopt [and embody in Odessa] all the best that he remembered in the harbors of Naples, Livorno and Genoa" [13, p. 174].

Over the next centuries, foreigners continued to contribute to the development of the economy and culture of the Azov-Black Sea region. In particular, the Greeks and the Italians played a role in the development of Taganrog, which was a notable percentage among local merchants (according to 1872, among 1087 Taganrog merchants there were 481 Greeks [2, p. 60]). Merchants not only developed the trade and economy of the city, their mansions adorned Taganrog and now they are monuments of architecture. Architect Francesco Carlo Boffo, the Italian in origin, built the famous Stone Staircase and two-storied classical gymnasium building in Taganrog. Active interaction and interpenetration of cultural traditions of different peoples and ethnic groups was carried out in the Azov-Black Sea region during the Soviet era. These processes continue today.

Thus, the study of ethno-cultural dynamics in the Azov-Black Sea region over centuries and thousands of years clearly demonstrates that the region, first, has historically acted as a crossroads of civilizations and, second, has been characterized by active intercultural interaction. The polarity of the migrations to the region, when representatives of the East and the West met in the Azov-Black Sea region, gave a significant identity to the intercultural contacts and their results. In the era of antiquity, the leading role in the process of cultural interaction in the Northern Black Sea region belonged to the Greeks and (to a lesser extent) the Romans as members of the developed Mediterranean civilizations, who stimulated the steppe nomads and accelerated their socio-economic and socio-political development. In the Middle Ages, when Greco-Roman cities in the region gradually fell into a decline or were destroyed altogether, the cultural balance in the Azov-Black Sea region changed in favor of nomads who were no longer represented by the Iranian-speaking and Turkic-speaking tribes. Still, despite the consistent dominance of the Huns, the Khazars, the Pechenegs, the Polovtsians and the Mongol-Tatars in the steppes of Pryazovia and the Black Sea region, Western influence had been still persisted, being represented by the Byzantine Empire and the Italian trade settlements. As a result, cultural interaction and interpenetration were 
maintained, although the degree of such contacts significantly decreased, compared to antiquity.

The unique outcome of ethnocultural contacts in the Azov-Black Sea region is the Cossacks, formed by the merger of representatives of various peoples and tribes of the region. The historical path taken by the Cossacks clearly proves that the commonalities that emerged during the intercultural exchange have a huge margin of strength.

It must be admitted that the interaction of the tribes and peoples of the Azov-Black Sea region with each other and, in particular, with the newly-arrived ethnic groups, had often been far from peaceful. This circumstance seems inevitable. The process of cultural interaction cannot be painless, it is aggravated and complicated by inter-ethnic clashes and conflicts. Nevertheless, the leading trend in the Azov-Black Sea region was the constant interaction of peoples and cultures, which mutually enriched their cultures and stimulated socio-economic and socio-political development. The analysis of the ethnocultural processes in the region suggests that intercultural communication is a condition for development, while autarky is fraught not only with the weakening of closed communities, but also with the variety of conflicts between these communities and their neighbors, which perceive isolation as a sign of weakness and hostility. We are convinced that only the existence of intercultural exchange that excludes autarky and xenophobia is one of the most important conditions for the development and prosperity of Russia as a multinational State.

\section{Лumepamypa}

1. Брашинский И.Б. Сокровища скифских царей. Поиски и находки. М., 1967. 128 с.

2. Гонтмахер М.А. Евреи на Донской земле. История, факты, биографии. Ростов н/Д., 2007.857 с.

3. История Дона и Северного Кавказа с древнейших времен до 1917 года / Под ред. А.И. Нарежного и Н.В. Самариной. Ростов н/Д., 2001. 463 с.

4. Кавказ и Дон в произведениях античных авторов / Отв. ред. М.Р. Гасанов. Ростов н/Д., 1990. 400 с.

5. Котошихин Г.К. О России в царствование Алексея Михайловича. М., 2000. 272 с.

6. Левченко В.С. Страницы донской истории. Ростов, 1974. 183 с.

7. Лунин Б.В. Очерки истории Подонья-Приазовья. В 2-х кн. Кн. 1. От древнейших времен до XVII столетия. Ростов н/Д., 1949. 184 с.

8. Мерперт Н.Я., Шелов Д.Б. Древности нашей земли. М., 1961. 240 с.

9. Регионоведение (Юг России: краткий тематический словарь) / Под общ. ред. Ю.Г. Волкова, А.В. Попова. Ростов н/Д., 2003. 689 с.

10. Скржинская М.В. Северное Причерноморье в описании Плиния Старшего. Киев, 1977. $126 \mathrm{c.}$.

11. Скрипов А.Н. На просторах Дикого поля. Ростов н/Д., 1973. 135 с.

12. Станиславский А.Л. Гражданская война в России XVII в.: Казачество на переломе истории. М., 1990. 270 с.

13. Эйдельман Н.Я. Твой восемнадцатый век. М., 1986. 286 с.

14. Энциклопедия культур народов Юга России. В 9 т. Т. 1. Народы Юга России. Ростов н/Д., 2005. 242 с.

\section{References}

1. Brashinsky I.B. Sokrovishcha skifskikh tsarei. Poiski i nakhodki. [Treasures of Scythian kings. Searches and discoveries]. Moscow, 1967. 128 p. (in Russian). 
2. Gontmacher M.A. Evrei na Donskoi zemle. Istoriia, fakty, biografii. [Jews on the Don Land. History, facts, biographies]. Rostov-on-Don, 2007. 857 p. (in Russian).

3. Istoriia Dona i Severnogo Kavkaza s drevneishikh vremen do 1917 goda. [History of Don and the North Caucasus from ancient times till 1917]. Under the editorship of A.I. Naregny and N.V. Samarina. Rostov-on-Don, 2001. 463 p. (in Russian).

4. Kavkaz i Don v proizvedeniiakh antichnykh avtorov. [Caucasus and Don in works of antique authors]. Editor-in-chief M.R. Gasanov. Rostov-on-Don, 1990. 400 p. (in Russian).

5. Kotoshikhin G.K. O Rossii v tsarstvovanie Alekseia Mikhailovicha. [About Russia in the reign of Alexei Mikhailovich]. Moscow, 2000. 272 p. (in Russian).

6. Levchenko V.S. Stranitsy donskoi istorii. [Pages of the Don history]. Rostov, 1974. 183 p. (in Russian).

7. Lunin B.V. Ocherki istorii Podonia-Priazovia. V 2-kh kn. Kn. 1. Ot drevneishikh vremen do XVII stoletiia. [Essays of the history of Podonye (territory in the Don River basin)Pryazovia. In 2 books. Book 1. From ancient times to the 17th century]. Rostov-onDon, 1949. 184 p. (in Russian).

8. Merpert N.Ya., Shelov D.B. Drevnosti nashei zemli. [Antiquity of our land]. Moscow, 1961. 240 p. (in Russian).

9. Regionovedenie (lug Rossii: kratkii tematicheskii slovar). [Regional Studies (South of Russia: Short Thematic Dictionary)]. Under the general editorship of Yu.G. Volkov, A.V. Popov. Rostov-on-Don, 2003. 689 p. (in Russian).

10. Skrzhinsky M.V. Severnoe Prichernomore v opisanii Pliniia Starshego. [Northern Black Sea region in the description of Pliny the Elder]. Kiev, 1977. 126 p. (in Russian).

11. Scripov A.N. Na prostorakh Dikogo polia. [On the spaces of the Wild Field]. Rostov-onDon, 1973. 135 p. (in Russian).

12. Stanislavsky A.L. Grazhdanskaia voina v Rossii XVII v.: Kazachestvo na perelome istorii. [Civil War in Russia of the 17th century: the Cossacks at a tipping point of history]. Moscow, 1990. 270 p. (in Russian).

13. Eidelman N.Ya. Tvoi vosemnadtsatyi vek. [Your eighteenth century]. Moscow, 1986. 286 p. (in Russian).

14. Entsiklopediia kultur narodov luga Rossii. V 9 t. T. 1. Narody luga Rossii. [Encyclopedia of cultures of the peoples of the South of Russia. In 9 volumes. V. 1. People of the South of Russia]. Rostov-on-Don, 2005. 242 p. (in Russian). 